34 Faria MA, Spector RH, Tindall GT. Downbeat nystagmus as the salient manifestation of the Arnold-Chiari malformation. Surg Neurol 1980;13:333-6.

35 Thrush DC, Foster JB. An analysis of nystagmus in 100 consecutive patients with syringomyelia. F Neurol Sci 1975;20:381-6.

36 Pederson RA, Troost T, Abel L, Zorub D. Intermittent downbeat nystagmus and ocillopsia reversed by suboccipital craniectomy. Neurology 1984;30(11):1239-42.

37 Hadj-Djilani M, Zander E. Follow up of 12 cases of cervicobulbar communicating syringohydromyelia 6-12 years after surgery. Neurochirurgie 1980;26:129-34.

38 Chung HD, DeMello DE, D'Souza N, Estrada J. Infantile syringobulbia. Neurology 1982;32:441-4.

39 Williams B. A critical appraisal of pcsterior fossa surgery for communicating syringomyelia. Brain 1978;101:223-50.

40 Roig C, Lopez-Pouza S, Ferrer I. Bleeding in syringobulbia. Eur Neurol 1982;21:189-93.
41 Ratcheson RA, Wirth FP, Cholu LI, Van Buren JM. Syringobulbia-prolonged survival. Acta Neurochir (Wein) 1971;24:169-77.

42 Taylor J, Greenfield JG, Martin JP. Two cases of syringomyelia and syringobulbia observed clinically over many years and examined pathologically. Brain many years and

43 Kruse A, Rassmussen G, Borgesen SE. CSF dynamics in syringomyelia: intracranial pressure and resistance to outflow. Br $\mathcal{F}$ Neurosurg 1987;1:477-84.

44 Staudenmaier C, Buncie JR. Periodic alternating gaze deviation with dissociated face turn. Arch Ophthal 1983;101:202-5.

45 Matsumoto T, Symon L. Surgical management of syringomyelia-current results. Surg Neurol 1989; 32:258-65.

46 Sherman JL, Citrin CM, Barkovich AJ. MR Imaging of syringobulbia. $f$ Comp Assist Tomography 1987; 11:407-11.

\section{The signs of Kernig and Brudzinski}

"I have observed for a number of years in cases of meningitis a symptom which is apparently rarely recognised although it is, in my opinion, of significant practical value. I am referring to the occurrence of flexion contractures in the legs or occasionally also in the arms which become evident only after the patient sits up.

Disregarding for a moment the infrequent cases of acute meningitis without contractures (particularly purulent secondary meningitis), one may find, as is well known, in the vast majority of cases of tuberculous and epidemic spinal meningitis the classic more or less prominent stiffness of the neck and back. Only in some of these patients while they are lying supine, may contractures of the extremity muscles be noted ... If one has the patient sit up on the edge of the bed, his legs dangling ... the stiffiness of the neck and back will ordinarily become much more severe and only now will a flexion contracture occur in the knee and occasionally also in the elbow joints. If one attempts to extend the patient's knees one will succeed only to an angle of approximately $135^{\circ}$. In cases in which this phenomenon is very pronounced, the angle may even remain at $90^{\circ} . "$

Vladimir Mihailovich Kernig (1840-1917) first brought these observations to the medical public at a meeting of physicians in St Petersburg in 1882. On 29 December 1884 his work was published.' Born in Lepaia, Latvia, Kernig graduated in 1864, receiving a doctorate one year later. He obtained a post at the
Obuhovsk Hospital in St Petersburg, reaching the highest professional rank and continued his work until his retirement in 1911. Kernig's account followed one year after that of the often confused Lasègue's sign described in his thesis by Lasègue's pupil J-J Forst in 1881.2

Jósef Brudzinski (1874-1917) was a Polish paediatrician. Dean of the University of Warsaw, he described several signs, but the one known in meningeal irritation was published in $1909 .^{3}$

"I have noted a new sign in cases of meningitis: passive flexion of the neck causes the lower extremities to flex at the knees and the pelvis... The technique of examination is very simple. With the child in the supine position, the examiner flexes the neck of the child with the left hand while resting his right hand on the patient's chest to prevent it from rising. This examination is generally not difficult except in the very young who because of restlessness may not be able to maintain the lower extremities in extension. In such a case, the examiner should gently restrain the legs at the knees. To prevent errors, it is important to do repeated examinations."

JMS PEARCE

1 Kernig W. Ueber ein wenig bemerktes MeningitisSymptom. Berlin Klin Wschr 1884;21:829-32.

2 Pearce JMS. $\mathcal{F}$ Neurol Neurosurg Pyychiatry 1988; 51:1157.

3 Brudzinski J. Un signe nouveau sur les membres inférieurs dans les meningités chez les enfants (signe de la nuque). Arch med Enf 1909;12:745-52. 